\title{
Terapi Menulis Ekspresif untuk Meningkatkan Kesejahteraan Subjektif Remaja dengan Lupus
}

\author{
Fakhrisina Amalia Rovieq ${ }^{1}$, Fuad Nashori ${ }^{2 *}$, Yulianti Dwi Astuti ${ }^{3}$ \\ Universitas Islam Indonesia Yogyakarta \\ 1'hellofakhrisina@gmail.com, ${ }^{2953200102 @ u i i . a c . i d, ~}{ }^{3}$ yulianti.dwiastuti@uii.ac.id \\ *Correspondence
}

Article Information:

Received 05 October 2020

Revised 14 April 2021

Accepted 15 April 2021

Keywords:

Expressive writing;

Subjective well-being;

Teenagers with lupus

\section{Kata Kunci:}

Kesejahteraan subjektif; Remaja dengan lupus; Terapi menulis ekspresif
Abstract

Lupus is an autoimmune disease that affects the physical condition and the individual's psychological. Lupus makes teenagers tend to have low subjective well-being. One of the intervention methods to improve personal well-being is through expressive writing. This research aims to observe the effectiveness of expressive writing to improve teenagers' subjective well-being with lupus. This research used one group pretest post-test design involving four people as the subjects $(\mathrm{N}=4)$. The data were collected using the measurement tools of Scale of Positive and Negative Experience (SPANE), Satisfaction with Life Scale (SWLS), interview, observation, and the results of the writing of the subjects during the therapy session. The results of the experimental research were in the form of quantitative analysis with the data analysis technique of the Krelated sample test, showing no significant change to the scores of the subjective well-being among the subjects after given the therapy of expressive writing. However, the qualitative results showed that definitive writing therapy could be a catharsis media for teenagers with lupus. Therefore, we can conclude that expressive writing is less effective in improving subjective wellbeing but can be used as a catharsis media for teenagers with lupus.

Abstrak
Lupus merupakan salah satu penyakit autoimun yang memberikan dampak tidak hanya kepada kondisi fisik, tapi juga kondisi psikologis individu yang menderitanya. Remaja dengan lupus cenderung memiliki kesejahteraan subjektif yang rendah. Salah satu metode intervensi yang dapat digunakan untuk meningkatkan kesejahteraan subjektif adalah menulis ekspresif. Penelitian ini bertujuan untuk mengetahui efektivitas menulis ekspresif untuk meningkatkan kesejahteraan subjektif remaja dengan lupus. Desain penelitian eksperimen ini adalah one group pretest post test design dengan jumlah subjek sebanyak empat orang $(\mathrm{N}=4)$. Pengumpulan data dilakukan dengan menggunakan alat ukur Scale of Positive and Negative Experience (SPANE), Satisfaction with Life Scale (SWLS), wawancara, observasi dan hasil tulisan subjek selama sesi terapi. Hasil penelitian berupa analisis kuantitatif dengan teknik analisis data $K$-related sample test, menunjukkan tidak ada perubahan signifikan pada skor 
kesejahteraan subjektif para subjek setelah diberikan terapi menulis ekspresif. Sedangkan hasil analisis kualitatif menunjukkan bahwa terapi menulis ekspresif dapat menjadi media katarsis bagi para remaja dengan lupus. Oleh karena itu, dapat disimpulkan bahwa menulis ekspresif kurang efektif dalam meningkatkan kesejahteraan subjektif namun dapat digunakan sebagai media katarsis remaja dengan lupus.

\section{PENDAHULUAN}

Lupus Eritematosus Sistemik (LES) atau Systemic Lupus Erythematosus (SLE) merupakan salah satu penyakit tidak menular yang diketahui sebagai faktor utama penyebab kematian. Berdasarkan data dari Pusat Data dan Informasi Kementerian Kesehatan Republik Indonesia, The Lupus Foundation of America memperkirakan sekitar 1,5 juta kasus lupus terjadi di Amerika dan setidaknya terjadi 5 juta kasus lupus di dunia. Selain itu, diperkirakan terjadi sekitar 16.000 kasus lupus baru setiap tahunnya. Meskipun data jumlah penderita penyakit lupus di Indonesia belum diketahui secara pasti, survei yang dilakukan Halim dkk di Malang menunjukkan bahwa 0,5\% dari total populasi di wilayah tersebut menderita lupus (Pusdatin, 2017). Di Daerah Istimewa Yogyakarta sendiri, penderita lupus yang terdeteksi pada tahun 2015 adalah sebanyak 2.000 orang dengan prevalensi lima penderita tiap 100.000 penduduk (gaya.tempo.co). Selain itu, Rumah Sakit Sardjito Yogyakarta juga merupakan pelapor tertinggi keempat atas kasus lupus baru, yaitu sebanyak 10,6\% dari total keseluruhan kasus yang dilaporkan pada tahun 2016 (Pusdatin, 2017).

Penyakit lupus kebanyakan menyerang wanita pada usia 15 - 50 tahun (usia produktif). Namun, lupus juga dapat menyerang anak-anak dan laki-laki. Berdasarkan data Sistem Informasi Rumah Sakit online, proporsi pasien rawat inap lupus perempuan lebih banyak dibandingkan laki-laki. Namun, jumlah pasien rawat inap laki-laki meningkat dua tahun setelahnya dan pada tahun 2016, jumlah pasien laki-laki yang menderita lupus mencapai 54,3\% dari populasi pasien lupus rawat inap (Pusdatin, 2017). Selain merasakan sakit fisik karena penyakit lupus, penderitanya juga dapat mengalami masalah psikologis dan sakit fisik yang dialaminya dapat menambah beban mental. Hal tersebut dapat memunculkan berbagai emosi negatif dan penurunan kepercayaan diri. Tentu hal ini menunjukkan bahwa odapus tidak hanya perlu mendapatkan penanganan obat-obatan untuk gejala fisiknya saja, tetapi juga perlu mendapatkan penanganan secara psikologis (Muzayanah, 2016).

Orang dengan penyakit lupus (biasa disebut odapus) mengalami berbagai hambatan terkait berbagai aspek di dalam hidupnya baik secara ekonomi, fisik, psikis maupun sosial. Berbagai hambatan tersebut meliputi mahalnya harga obat yang harus ditebus yang mencapai angka puluhan juta rupiah, kondisi tubuh yang mudah sekali lelah, sakit sendi dan otot, larangan terpapar matahari secara langsung, perubahan tubuh karena efek samping obat-obatan yang dikonsumsi, bercak kemerahan yang muncul pada wajah, rambut rontok, kulit bersisik dan mengelupas, nyeri pada sendi, bagian tubuh yang sulit 
digerakkan serta memar pada tubuh yang muncul secara tiba-tiba (Mahardhika \& Halimah, 2017). Berbagai kondisi tersebut yang memberatkan baik secara ekonomi, fisik, psikis maupun sosial tersebut membuat odapus cenderung memiliki masalah psikologis dan mengalami emosi yang negatif. Selain itu, Karasz dan Oulette (Mcelhone dkk., 2006) menyatakan bahwa lupus dapat menyebabkan seseorang mengalami hambatan dalam peran sosial mereka sehingga hal ini memberikan dampak negatif pada kesejahteraan odapus. Selain itu, Kulczycka, Sysa-Jedrzejowska dan Robak (2010) menemukan bahwa odapus menilai bahwa kualitas dan kepuasan hidup yang dimiliki mereka rendah.

Terkait dengan kesejahteraan Odapus, ada konsep yang digunakan untuk memahami keadaan mereka, yaitu kesejahteraan subjektif (subjective well-being) (Diener, 1984). Oleh Diener diungkapkan bahwa kesejahteraan subjektif merupakan sebuah konsep yang meliputi evaluasi individu terhadap hidupnya baik dari sisi kognitif maupun afektif. Evaluasi ini terdiri atas reaksi emosi terhadap sebuah peristiwa dan penilaian kognitif terhadap kepuasan serta pemenuhan diri dan disebut sebagai kesejahteraan subjektif. Kesejahteraan subjektif dimaknai sebagai sebuah konsep luas di mana individu mengalami banyak emosi menyenangkan, tingkat emosi negatif yang rendah, dan kepuasan hidup yang tinggi (Snyder \& Lopez, 2001). Kesejahteraan subjektif dapat dipengaruhi oleh beberapa faktor, seperti amanah, dukungan sosial (Hasibuan dkk., 2018), mindfulness (Rahmawati dkk., 2020), pertaubatan dan kontrol diri (Ekayani dkk., 2020), harga diri (Ryan \& Deci, 2001), kepribadian dan faktor genetik (Steel dkk., 2008), pengaruh sosial (Fowler \& Christakis, 2008), faktor ekonomi (Aknin dkk., 2009), kesehatan (Ed Diener \& Chan, 2011), serta waktu luang dan rekreasi (Hribernik \& Mussap, 2010).

Intervesi-intervensi untuk odapus yang pernah diberikan kebanyakan menggunakan metode komunikasi maupun pengekspresian emosi secara verbal. Intervensi dengan metode ini tentu memiliki kelemahan karena dalam intervensi yang menggunakan metode komunikasi verbal, individu dapat menjadi kurang mampu mengekspresikan emosi dan menceritakan masalahnya kepada orang lain. Beberapa penyebabnya adalah individu kesulitan dalam menemukan pendengar yang simpatik dan suportif, atau pengalaman mendapatkan respons dari pendengar yang seringkali tidak pantas atau tidak sensitif sehingga individu tersebut lebih memilih untuk tidak membicarakan trauma maupun emosi mereka (Nazarian \& Smyth, 2008).

Untuk meminimalisasi adanya hambatan dalam pengekspresian emosi tersebut, maka diperlukan intervensi lain yang membuat individu dapat merasa lebih bebas untuk mengekspresikan diri dan emosi mereka. Metode menulis ekspresif dinilai dapat membuat individu lebih mampu mengekspresikan emosi tanpa penghalang dan konsekuensi negatif seperti yang mungkin terjadi dalam pengungkapan diri dalam terapi bicara (Nazarian \& Smyth, 2008).

Selama dua dekade, penelitian mengenai terapi menulis ekspresif telah menemukan bahwa menulis tentang emosi yang berkaitan dengan kejadian negatif dalam 
hidup menghasilkan hasil yang positif bagi individu seperti meningkatnya kesehatan fisik. Selain itu, menuliskan secara acak pikiran-pikiran dan perasaan terkait peristiwa yang menimbulkan stres atau pengalaman-pengalaman traumatis menunjukkan pelaporan kesehatan yang lebih baik, meningkatkan kekebalan tubuh, meringankan rasa sakit, meringankan rasa lelah dan meningkatkan kesejahteraan psikologis individu (DanoffBurg dkk., 2006). Dengan demikian diharapkan melalui terapi menulis ekspresif, penderita lupus dapat mengekspresikan perasaan-perasaan negatif di dalam dirinya dan lebih mampu menerima kondisinya. Aktivitas menulis ekspresif tersebut diharapkan dapat meningkatkan kesejahteraan subjektif pada remaja dengan lupus.

Berdasarkan penjelasan di atas, dapat dirumuskan tujuan dari penelitian ini adalah untuk mengetahui efektivitas terapi menulis ekspresif dalam meningkatkan kesejahteraan subjektif pada remaja yang memiliki penyakit lupus. Adapun yang menjadi hipotesis pada penelitian ini adalah terdapat peningkatan kesejahteraan subjektif pada remaja dengan lupus setelah diberikan intervensi berupa terapi menulis ekspresif.

\section{METODE}

Desain penelitian yang digunakan dalam penelitian ini adalah mix-method research. Metode kuantitatif dilakukan dengan menggunakan desain penelitian kuasi eksperimen. Jenis desain eksperimen yang digunakan dalam penelitian ini adalah one group pretest-post test design. Sementara penelitian kualitatif dilakukan dengan desain fenomenologi.

Subjek penelitian yang terlibat dalam penelitian ini berjumlah empat orang $(\mathrm{N}=4)$ yang memiliki kriteria sebagai berikut: (1) Remaja yang memiliki penyakit lupus, (2) berusia 15 - 21 tahun, (3) berdomisili di Daerah Istimewa Yogyakarta, (14) bersedia mengikuti intervensi dari awal sampai selesai, memiliki tingkat kesejahteraan subjektif rendah sampai sedang, serta tidak sedang menjalani intervensi/tritmen psikologis lain.

Metode pengumpulan data yang digunakan oleh peneliti adalah metode wawancara, observasi dan skala. Wawancara dan observasi dilakukan untuk mendapatkan data kualitatif, sementara skala digunakan untuk mendapatkan data kuantitatif. Wawancara, observasi, dan pengisian lembar kerja dimaksudkan untuk mendapatkan data kualitatif dari subjek. Wawancara dilakukan dengan mengajukan sejumlah pertanyaan seputar terapi menulis ekspresif dan kesejahteraan subjektif. Observasi dilakukan dengan mengamati peran subjektif selama mengikuti terapi menulis ekspresif. Lembar kerja merupakan form isian dari subjek terkait pengalamannya selama mengikuti kegiatan terapi menulis ekspresif.

Dua skala yang digunakan dalam penelitian ini ada dua, yaitu Scale of Positive and Negative Experience (SPANE) dan Satisfaction with Life Scale (SWLS). Keduanya dimaksudkan untuk mengukur dua dimensi kesejahteraan subjektif sebagaimana dikonseptualisasi oleh Diener (1984), yaitu kepuasan hidup dan afeksi. SPANE merupakan alat ukur afek positif dan afek negatif yang dikembangkan oleh Diener, Wirtz,

82 | Journal An-Nafs: Kajian Penelitian Psikologi, Vol. 6 No. 1 Juni 2021 
Tov, Kim-Prieto, Choi, Oishi, dan Biswas-Diener (2010). Beberapa kata yang dijadikan aitem dalam skala ini adalah "Bahagia", "Sedih", "Khawatir", "Gembira", "Marah", dan "Puas". Reliabilitas pada alat ukur SPANE terbagi menjadi dua yaitu koefisien reliabilitas negative affect sebesar 0,677 dan koefisien reliabilitas positive affect sebesar 0,776 (Ulfah, 2015).

Sementara itu SWLS merupakan alat ukur kepuasan hidup yang dikembangkan Diener, Emmons, Larsen, dan Griffin (1985). Contoh tiga aitem SWLS adalah "Saya benar-benar puas dengan hidup saya", "Sejauh ini, saya telah memperoleh apa yang saya inginkan", dan "Jika saya bisa mengulang hidup saya, saya tidak akan mengubah apa pun." Reliabilitas pada SWLS diketahui dari koefisien alpha pada SWLS adalah sebesar 0,71 (Ulfah, 2015).

Penelitian ini dilakukan dalam dua tahapan, yaitu tahap persiapan dan tahap pelaksanaan. Dalam tahap pelaksanaan, peneliti mempersiapkan keperluan penelitian dan intervensi seperti wawancara dan observasi awal, penyusunan modul intervensi, pemilihan observer penelitian, serta pemilihan terapis.

Setelah melakukan tahap persiapan, peneliti mulai melakukan tahap pelaksanaan intervensi yang dijadwalkan sebanyak 19 sesi dalam 3 kali pertemuan, dengan rincian pertemuan 1 sebanyak 8 sesi, pertemuan 2 sebanyak 5 sesi dan pertemuan 3 sebanyak 6 sesi. Peserta akan mendapatkan psikoedukasi tantang apa, bagaimana, dan manfaat expressive writing therapy pada pertemuan pertama dan intervensi expressive writing therapy yang diulang pada pertemuan-pertemuan selanjutnya. Proses ini dilanjutkan dengan follow up dua minggu setelah intervensi selesai untuk melihat efektivitas intervensi terhadap para partisipan.

Tabel 1. Pelaksanaan intervensi

\begin{tabular}{|c|c|c|c|}
\hline $\begin{array}{c}\text { Pertemuan/ } \\
\text { Sesi }\end{array}$ & Kegiatan & Waktu & Tujuan \\
\hline $\mathrm{I} / 2$ & $\begin{array}{l}\text { Pembukaan dan } \\
\text { perkenalan }\end{array}$ & $15^{\prime}$ & $\begin{array}{l}\text { Menjadi pembuka kegiatan dan menjalin } \\
\text { keakraban antar individu yang terlibat } \\
\text { dalam proses intervensi }\end{array}$ \\
\hline $\mathrm{I} / 2$ & $\begin{array}{lr}\text { Tujuan } & \text { kegiatan } \\
\text { dan } & \text { informed } \\
\text { consent } & \end{array}$ & $10^{\prime}$ & $\begin{array}{l}\text { Menjelaskan tujuan kegiatan kepada } \\
\text { peserta dan memperoleh persetujuan } \\
\text { peserta dalam mengikuti seluruh rangkaian } \\
\text { kegiatan }\end{array}$ \\
\hline $\mathrm{I} / 3$ & $\begin{array}{l}\text { Penjelasan tentang } \\
\text { terapi menulis } \\
\text { ekspresif }\end{array}$ & $15^{\prime}$ & $\begin{array}{l}\text { Peserta mendapatkan penjelasan tentang } \\
\text { intervensi yang dilakukan dan mengetahui } \\
\text { manfaat yang diperoleh setelah intervensi }\end{array}$ \\
\hline $\mathrm{I} / 4$ & Ice Breaking & $10^{\prime}$ & $\begin{array}{l}\text { Membuat suasana yang nyaman bagi } \\
\text { peserta dan membangun keakraban antara } \\
\text { peserta dan terapis }\end{array}$ \\
\hline $\mathrm{I} / 5$ & $\begin{array}{l}\text { Instruksi terapi } \\
\text { menulis ekspresif }\end{array}$ & $15^{\prime}$ & $\begin{array}{l}\text { Memberikan penjelasan mengenai } \\
\text { instruksi kegiatan kepada peserta }\end{array}$ \\
\hline $\mathrm{I} / 6$ & $\begin{array}{l}\text { Terapi menulis } \\
\text { ekspresif }\end{array}$ & $30^{\prime}$ & $\begin{array}{l}\text { Peserta melakukan kegiatan menulis } \\
\text { sesuai dengan aturan yang telah dijelaskan } \\
\text { sebelumnya }\end{array}$ \\
\hline
\end{tabular}




\begin{tabular}{|c|c|c|c|}
\hline $\mathrm{I} / 7$ & $\begin{array}{l}\text { Pengisian lembar } \\
\text { kerja }\end{array}$ & 15 & $\begin{array}{l}\text { Peserta mengisi lembar kerja mengenai } \\
\text { kondisi yang dirasakan selama proses } \\
\text { menulis }\end{array}$ \\
\hline $\mathrm{I} / 8$ & Penutup kegiatan & 10 & $\begin{array}{l}\text { Membuat kesimpulan kegiatan dan } \\
\text { memotivasi peserta untuk tetap semangat } \\
\text { mengikuti kegiatan selanjutnya. }\end{array}$ \\
\hline II/9 & $\begin{array}{l}\text { Pembukaan } \\
\text { kegiatan }\end{array}$ & $15^{\prime}$ & $\begin{array}{l}\text { Membuka kegiatan dan menanyakan } \\
\text { kondisi peserta }\end{array}$ \\
\hline $\mathrm{II} / 10$ & $\begin{array}{l}\text { Instruksi terapi } \\
\text { menulis ekspresif }\end{array}$ & $15^{\prime}$ & $\begin{array}{l}\text { Memberikan penjelasan mengenai } \\
\text { instruksi kegiatan kepada peserta }\end{array}$ \\
\hline II/11 & $\begin{array}{l}\text { Terapi menulis } \\
\text { ekspresif }\end{array}$ & 30 & $\begin{array}{l}\text { Peserta melakukan kegiatan menulis } \\
\text { sesuai dengan aturan yang telah dijelaskan } \\
\text { sebelumnya }\end{array}$ \\
\hline $\mathrm{II} / 12$ & $\begin{array}{l}\text { Pengisian lembar } \\
\text { kerja }\end{array}$ & 15 & $\begin{array}{l}\text { Peserta mengisi lembar kerja mengenai } \\
\text { kondisi yang dirasakan selama proses } \\
\text { menulis }\end{array}$ \\
\hline II/13 & Penutup kegiatan & $10^{\prime}$ & $\begin{array}{l}\text { Membuat kesimpulan kegiatan dan } \\
\text { memotivasi peserta untuk tetap semangat } \\
\text { mengikuti kegiatan selanjutnya. }\end{array}$ \\
\hline III/14 & $\begin{array}{l}\text { Pembukaan } \\
\text { kegiatan }\end{array}$ & 15 & $\begin{array}{l}\text { Membuka kegiatan dan menanyakan } \\
\text { kondisi peserta }\end{array}$ \\
\hline III/15 & $\begin{array}{l}\text { Instruksi terapi } \\
\text { menulis ekspresif }\end{array}$ & 15 & $\begin{array}{l}\text { Memberikan penjelasan mengenai } \\
\text { instruksi kegiatan kepada peserta }\end{array}$ \\
\hline III/16 & $\begin{array}{ll}\text { Terapi } & \text { menulis } \\
\text { ekspresif } & \end{array}$ & 30 & $\begin{array}{l}\text { Peserta melakukan kegiatan menulis } \\
\text { sesuai dengan aturan yang telah dijelaskan } \\
\text { sebelumnya }\end{array}$ \\
\hline III/17 & $\begin{array}{l}\text { Pengisian lembar } \\
\text { kerja }\end{array}$ & 15 & $\begin{array}{l}\text { Peserta mengisi lembar kerja mengenai } \\
\text { kondisi yang dirasakan selama proses } \\
\text { menulis }\end{array}$ \\
\hline III/18 & Penutup kegiatan & $10^{\prime}$ & $\begin{array}{l}\text { Membuat kesimpulan kegiatan secara } \\
\text { keseluruhan dari pertemuan pertama } \\
\text { sampai terakhir }\end{array}$ \\
\hline III/19 & $\begin{array}{l}\text { Evaluasi dan post- } \\
\text { test }\end{array}$ & 15 & $\begin{array}{l}\text { Peserta memberikan evaluasi dan mengisi } \\
\text { post-test untuk mengetahui perubahan } \\
\text { yang terjadi setelah diberikan intervensi }\end{array}$ \\
\hline
\end{tabular}

Teknik analisis data yang digunakan dalam penelitian ini adalah Teknik analisis non-parametrik k-related sample test. Uji analisis data ini akan dilakukan dengan menggunakan SPSS 16 for windows. Selanjutnya, data kualitatif dicoba analisis dengan mendasarkan pada content analysis. Ada tiga tahap koding dalam analisis kualitatif ini, yaitu Open Coding, Axial Coding, dan Selective Coding. Open coding dilakukan dengan cara memberi kode untuk seluruh teks. Setelahnya, teks yang dalam bentuk baris ber baris itu diberi tema yang berbeda. Selanjutnya adalah tahap Axial Coding, yaitu tema-tema yang ada dimasukkan dalam kategori-kategori. Terakhir adalah Selective Coding, yang dilakukan dengan cara mencari hubungan antar kategori. Pada tahap ini tema baru dapat juga dikembangkan.

\section{PAPARAN HASIL}


Berikut ini akan disampaikan hasil analisis data yang melibatkan data prates, pascates, dan follow up.

Tabel 2. Uji Beda Skor Prates-Pascates-Follow Up

\begin{tabular}{cc}
\hline Aspek/Variabel & P \\
\hline Afek Positif & 0,735 \\
Afek Negatif & 0,607 \\
Keseimbangan Afek & 0,584 \\
Kepuasan Hidup & 0,441 \\
Kesejahteraan subjektif & 0,097 \\
\hline Tabel 3. Uji Beda Skor Prates-Pascates & $\mathbf{P}$ \\
\hline Aspek/Variabel & 0,564 \\
Afek Positif & 0,317 \\
Afek Negatif & 0,157 \\
Keseimbangan Afek & 0,564 \\
Kepuasan Hidup & 0,083 \\
Kesejahteraan subjektif
\end{tabular}

Tabel 4. Uji Beda Skor Pascates-Follow Up

\begin{tabular}{cc}
\hline Aspek/Variabel & P \\
\hline Afek Positif & 0,564 \\
Afek Negatif & 0,317 \\
Keseimbangan Afek & 0,564 \\
Kepuasan Hidup & 0,157 \\
Kesejahteraan subjektif & 0,083 \\
\hline
\end{tabular}

Tabel 5. Uji Beda Skor Prates-Follow Up

\begin{tabular}{cc}
\hline Aspek/Variabel & P \\
\hline Afek Positif & 0,564 \\
Afek Negatif & 1,000 \\
Keseimbangan Afek & 1,000 \\
Kepuasan Hidup & 0,564 \\
Kesejahteraan subjektif & 0,564 \\
\hline
\end{tabular}

Hasil uji hipotesis pada seluruh tabel di atas (table 1, table 2, table 3, dan table 4) menunjukkan bahwa nilai signifikansi yang diperoleh oleh seluruh data adalah $\mathrm{p}>0,05$. Dengan demikian, dapat dikatakan bahwa tidak ada perbedaan yang signifikan terhadap kesejahteraan subjektif (afek positif-negatif maupun kepuasan hidup) para subjek setelah diberikan intervensi berupa terapi menulis ekspresif.

Selain hasil analisis kuantitatif, pada penelitian ini juga didapatkan data dari proses intervensi, bahwa terapi menulis ekspresif menjadi media katarsis bagi para subjek. Hal ini ditunjukkan oleh hasil lembar kerja dan hasil wawancara pada saat pengukuran follow up. Semua subjek menyatakan bahwa menulis ekspresif membuat mereka merasa lebih lega dan dapat menyalurkan emosi mereka.

Responden pertama, YS (perempuan, 19 tahun), merasa lelah dan berat menjalani hari-harinya sebagai penderita lupus. Namun, subjek mengetahui coping yang bisa 
dilakukan ketika merasa ada masalah, yaitu menulis dan mengaji. "Jujur aku kalau ada masalah iya nulis ... tapi tambah plong lagi kalau ngaji dan baca artinya.." (hal. 2 baris 8). Subjek juga menyebutkan pada saat membuat tulisan, subjek mampu mengungkapkan hal-hal yang tidak bisa diungkapkan sehingga subjek merasa plong. Subjek juga merasa lebih enak dan lega setelah selesai menulis karena merasa uneg-unegnya sudah keluar. Selain itu subjek merasa kegiatan menulis pada pertemuan ini membuat mengekspresikan diri menjadi lebih asyik. Ungkapan subjek ini menunjukkan bahwa dari aspek kepuasan hidup, ia merasakan adanya kesejahteraan hidup yang bertambah.

Subjek kedua, QRH (perempuan, 18 tahun), mengungkapkan bahwa aktivitas menulis ekspresif pada awalnya memunculkan emosi marah dan sedikit rasa sedih. Subjek menuliskan bahwa setelah menulis beberapa kali lama-lama subjek dapat mengontrol emosinya. Subjek juga menilai bahwa menulis merupakan hal yang cukup menyakitkan tapi dapat dijadikan review untuk ke depannya. Selanjutnya, subjek menuliskan pada lembar kerja bahwa tulisan menimbulkan perasaan lucu dan senang dan perasaan subjek setelah menuliskannya menjadi cukup lega. Hal ini menunjukkan bahwa secara dari aspek emosi, subjek secara relatif merasakan hadirnya emosi positif.

Subjek ketiga, KMK (perempuan, 19 tahun), menuliskan bahwa dirinya merasa sedikit lega setelah selesai menulis dan baru mengetahui bahwa ternyata menulis bisa membuat perasaan menjadi lebih lega. Subjek mengatakan dan menuliskan di lembar kerja bahwa dirinya merasa lebih lega dan emosi dari masalah yang dituliskan ikut keluar selama subjek menuliskannya. Pada saat pertemuan tindak lanjut, subjek mengatakan bahwa terapi menulis ekspresif membuat rasa tidak nyaman subjek berkurang. Subjek merasa menemukan jalan keluar untuk dapat bercerita yaitu dengan menuliskannya. Subjek mengatakan akan melanjutkan menulis di rumah meskipun terapi sudah selesai. Keadaan ini menunjukkan terapi menulis ekspresif membantu peningkatan kepuasan hidup subjek.

Subjek keempat, RW (perempuan, 19 tahun), menuliskan bahwa dirinya merasa lega dan plong setelah selesai menulis. Subjek juga menyatakan bahwa uneg-uneg dan perasaan subjek terwakilkan melalui tulisan tersebut. Berdasarkan hasil observasi, subjek tampak terus menulis selama sesi terapi hingga waktu selesai. Subjek juga banyak menunduk ketika sesi sharing di akhir pertemuan, tetapi subjek tidak menunjukkan ekspresi selain tersenyum ketika berinteraksi dengan terapis dan menyampaikan bahwa subjek merasa aktivitas terapi menulis ekspresif yang sudah dilakukan membuat subjek merasa lebih plong. Kondisi ini menunjukkan terapi menulis ekspresif membantu peningkatan kepuasan hidup.

\section{PEMBAHASAN}

Penelitian ini memiliki tujuan untuk mengetahui efektivitas menulis ekspresif dalam meningkatkan kesejahteraan subjektif remaja yang memiliki penyakit lupus. Berdasarkan hasil penelitian yang telah dilakukan secara kuantitatif didapatkan hasil 
bahwa terapi menulis ekspresif kurang efektif untuk meningkatkan kesejahteraan subjektif pada remaja dengan lupus, sehingga hipotesis penelitian ditolak.

Hasil analisis kuantitatif menunjukkan bahwa tidak terjadi peningkatan yang signifikan pada skor prates, pascates dan follow up skala SPANE, SWLS dan skor total prates, pascates serta follow up kesejahteraan subjektif para subjek secara keseluruhan. Berdasarkan data yang diperoleh selama proses intervensi berlangsung dan dikaitkan dengan teori yang ada, maka ditemukan beberapa faktor yang dapat mempengaruhi menulis ekspresif tidak efektif dalam meningkatkan kesejahteraan subjektif pada remaja dengan lupus. Beberapa di antaranya adalah tidak terpenuhinya karakteristik terapi menulis ekspresif, topik yang diungkap oleh para subjek dalam tulisannya, jarak terapi menulis, kondisi kesehatan serta faktor-faktor eksternal lain yang tidak dapat dikontrol oleh peneliti.

Menulis ekspresif memiliki beberapa karakteristik salah satunya adalah selfexpression, yaitu digunakan sebagai sarana atau wadah untuk mengungkapkan perasaan dan persepsi menjadi pemahaman diri yang lebih baik atau menghasilkan emosi yang lebih baik, pemecahan masalah dan perasaan well-being (Malchiodi, 2007). Berdasarkan hasil menulis ekspresif, diketahui bahwa beberapa subjek belum memperlihatkan selfexpression saat mengikuti terapi menulis ekspresif. Meskipun dari hasil tulisan para subjek mampu mengungkapkan perasaan dan pikiran terkait pengalaman masa lalu, tetapi hanya subjek RW yang terlihat memunculkan pemahaman dan penerimaan terkait pengalaman masa lalunya. Sementara subjek yang lain hanya menuliskan tentang pengalaman dan perasaan yang muncul saat mengalami hal tersebut sehingga belum memunculkan proses kognitif terhadap pemahaman dan penerimaan diri lebih baik ataupun pemecahan masalah sebagaimana yang dinyatakan oleh Pluth (2012) bahwa pada proses kognitif, terjadi proses menganalisis dan mempelajari hal-hal baru dari pengalaman emosional yang dialami.

Berdasarkan data yang didapatkan dari hasil penelitian, para subjek cenderung menuliskan pengalaman traumatis atau tidak menyenangkan yang dialami pada masa lalu dibandingkan menuliskan pengalaman traumatis atau tidak menyenangkan yang dialami pada masa kini. Soper dan Bergen (2001) mengemukakan bahwa topik yang diungkapkan oleh individu saat menulis terkait trauma yang dialami berhubungan dengan hasil yang diperoleh. Individu yang menulis mengenai trauma yang saat ini dialaminya memperlihatkan hasil well-being yang lebih tinggi dibandingkan dengan individu yang menulis mengenai trauma pada masa lalu dan saat ini secara bersamaan.

Faktor lain yang dapat menyebabkan terapi menulis ekspresif yang diberikan menjadi tidak efektif adalah pelaksanaan terapi menulis ekspresif yang dilaksanakan dalam jangka waktu satu minggu sekali. Padahal, metode pemberian terapi ini secara klasik oleh Pennebaker dan Beall (1986) diberikan secara berturut-turut selama beberapa hari. Hal ini berkaitan dengan penelitian Smyth (1998) dan penelitian Soper dan Bergen (2001) yang menemukan adanya pengaruh yang lebih kuat terkait dengan jarak 
pemberian tritmen terhadap efektivitas menulis ekspresif. Selain itu Smyth juga mengemukakan bahwa proses terapeutik dapat meningkat selama beberapa periode waktu, yang dapat meningkatkan manfaat dari menulis. Semakin lama terapi menulis ekspresif diberikan maka semakin memungkinkan meningkatnya proses terapeutik. Hal ini belum dipenuhi dalam penelitian ini yang hanya memberikan sesi terapi menulis ekspresif selama tiga kali.

Kondisi kesehatan juga merupakan salah satu faktor yang mempengaruhi kondisi kesejahteraan subjektif individu. Individu dengan yang menilai kondisi kesehatannya kurang baik cenderung memiliki kondisi kesejahteraan subjektif yang rendah juga (Okun dkk., 1984). Hal ini tejadi pada saat pengukuran tindak lanjut di mana beberapa subjek sedang berada dalam kondisi kurang sehat sehingga mempengaruhi penilaian subjek terhadap dirinya sendiri pada saat diberikan pengukuran tindak lanjut.

Toepfer dan Walker (2009) menemukan bahwa kebahagiaan dan kepuasan hidup yang merupakan komponen dari kesejahteraan subjektif meningkat setelah diberikan terapi menulis ekspresif. Namun, penjelasan di atas menunjukkan bahwa terapi menulis ekspresif yang digunakan dalam penelitian ini kurang sesuai untuk mengintervensi kesejahteraan subjektif remaja dengan lupus. Hal ini dapat disebabkan dalam penelitian ini, hanya subjek RW yang telah menuliskan emosi yang lebih positif terkait pengalaman yang dialami setelah melakukan proses kognitif berupa reframing terhadap masalah dengan cara melihat masalah yang dialami dengan sudut pandang yang lebih positif. Sedangkan, subjek yang lain masih melakukan recalling mengenai pikiran dan perasaan negatif hingga sesi terakhir. Padahal menurut Toepfer dan Walker (2009), peningkatan kebahagiaan dan kepuasan hidup dapat terjadi pada individu yang menuliskan hal-hal positif di dalam hidupnya. Hal ini juga berkaitan dengan lamanya waktu pemberian terapi yang membuat para subjek baru dapat mengekspresikan emosi negatif saja dan belum dapat melakukan evaluasi terkait masalahnya.

Meskipun terapi menulis ekspresif ini tidak efektif dalam meningkatkan kesejahteraan subjektif remaja dengan lupus, pada grafik pengukuran skor terlihat bahwa terjadi peningkatan skor rerata afek positif, keseimbangan afek, kepuasan hidup dan kesejahteraan subjektif serta penurunan skor rerata afek negatif pada saat pengukuran pascates. Hal tersebut menunjukkan bahwa pemberian terapi menulis ekspresif dapat meningkatkan rerata afek positif, keseimbangan afek, kepuasan hidup dan kesejahteraan subjektif serta menurunkan nilai rerata afek negatif para subjek secara keseluruhan pada saat terapi baru selesai diberikan. Oleh karena itu dapat dikatakan bahwa terapi menulis ekspresif dapat membantu para subjek melepaskan atau mengungkapkan perasaan yang dialami.

Fivush, Reynold, dan Brewin (2007) mengatakan bahwa ketika individu mengalami kesulitan atau hambatan untuk mengungkapkan pikiran dan emosi yang menganggu, maka ketika pikiran dan emosi tersebut dapat dilepaskan atau diungkapkan akan memberikan katarsis bagi individu. Hal ini juga didukung oleh data kualitatif dari

88 | Journal An-Nafs: Kajian Penelitian Psikologi, Vol. 6 No. 1 Juni 2021 
penelitian ini. Para subjek merasa sedikit lebih baik dan lega karena dapat mengungkapkan emosi-emosi mereka melalui tulisan. Hal ini terlihat dari wawancara dan lembar kerja yang ditulis oleh para subjek pada akhir pertemuan. Para subjek juga menyatakan hal tersebut pada saat pertemuan follow up di mana seluruh subjek menyatakan bahwa terapi menulis ekspresif yang telah dilaksanakan membuat mereka bisa lebih lega. Hal tersebut dikarenakan responden sudah sudah menyampaikan apa yang selama ini tidak dapat mereka sampaikan atau ceritakan secara verbal kepada orang lain.

\section{SIMPULAN}

Berdasarkan hasil penelitian yang telah dilakukan, dapat disimpulkan bahwa terapi menulis ekspresif kurang efektif dalam meningkatkan kesejahteraan subjektif remaja dengan lupus. Meski demikian, aktivitas menulis ekspresif membuat mereka merasa lebih lega dan dapat menyalurkan emosi mereka.

Peningkatan yang terjadi pada pengukuran pascates dapat disebabkan terapi menulis ekspresif membantu para subjek untuk melepaskan emosi negatif yang selama ini terhambat sehingga para subjek merasakan kelegaan dan emosi positif yang lebih baik pada saat pengukuran pascates. Adapun hasil analisis kuantitatif yang tidak signifikan dapat disebabkan oleh beberapa faktor seperti tidak terpenuhinya karakteristik terapi menulis ekspresif, topik yang diungkap oleh para subjek dalam tulisannya, kondisi kesehatan serta faktor-faktor eksternal lain yang tidak dapat dikontrol oleh peneliti.

\section{REKOMENDASI}

Beberapa hal yang dapat dijadikan saran berdasarkan penelitian yang telah dilakukan ini. Adapun saran-saran tersebut agar dapat dipertimbangkan dalam penelitian selanjutnya dengan tema atau pun penelitian yang serupa. Bagi peneliti selanjutnya disarankan untuk dapat menambahkan jumlah subjek penelitian dan memberikan kelompok kontrol sehingga dapat membandingkan hasil antar kelompok yang diberikan intervensi dengan yang tidak diberikan intervensi.

Saran lain yang dapat dijadikan bahan pertimbangan untuk pelaksanaan penelitian yang serupa di masa yang akan datang adalah adanya tambahan sesi menulis bukan hanya pengalaman traumatis atau emosi dan pikiran negatif yang mengganggu saja, namun juga menuliskan pengalaman menyenangkan sehingga peserta penelitian tidak hanya mengalami kembali emosi negatif saja, namun juga emosi positif. Selain itu, untuk penelitian selanjutnya disarankan untuk memberikan terapi menulis dengan jeda yang tidak terlalu lama, atau jika waktu pelaksanaan tidak memungkinkan, maka sebaiknya para subjek penelitian diberikan PR untuk tetap menulis selama di rumah agar proses terapi tetap berjalan. Tambahan sesi menulis ekspresif juga disarankan agar para subjek penelitian dapat lebih mengalami proses terapeutik dalam terapi menulis ekspresif.

Selain itu, terapi menulis sebaiknya dikombinasikan dengan terapi yang lain juga sebab terapi menulis cenderung hanya mampu membantu individu melakukan katarsis. 
Sehingga, jika tujuan penelitian bukan untuk membantu individu melakukan katarsis saja, terapi menulis ekspresif sebaiknya dikombinasikan dengan terapi lain yang sesuai dengan tujuan penelitian.

Prosedur pemberian terapi menulis ekspresif sebaiknya disesuaikan/dimodifikasi dengan dilakukan uji modul terlebih dahulu sebelum digunakan dalam pemberian intervensi. Dengan demikian diharapkan dapat meminimalisasi kesalahan atau kekurangan dalam pelaksanaan intervensi.

\section{DAFTAR PUSTAKA}

Aknin, L. B., Norton, M. I., \& Dunn, E. W. (2009). From wealth to well-being? Money matters, but less than people think. The Journal of Positive Psychology, 4(6), 523527. https://doi.org/10.1080/17439760903271421

Danoff-Burg, S., Agee, J. D., Romanoff, N. R., Kremer, J. M., \& Strosberg, J. M. (2006). Benefit finding and expressive writing in adults with lupus or rheumatoid arthritis. $\begin{array}{llll}\text { Psychology } \quad \text { Health, } & \text { 21(5), 651-665. }\end{array}$ https://doi.org/10.1080/14768320500456996

Diener, E., Emmons, R. A., Larsen, R. J., \& Griffin, S. (1985). The Satisfaction With Life Scale. Journal of Personality Assessment, 49(1), 71-75. https://doi.org/10.1207/s15327752jpa4901_13

Diener, Ed. (1984). Subjective well-being. Psychological Bulletin, 95(3), 542-575. https://doi.org/10.1037/0033-2909.95.3.542

Diener, Ed, \& Chan, M. Y. (2011). Happy People Live Longer: Subjective Well-Being Contributes to Health and Longevity: HEALTH BENEFITS OF HAPPINESS. Applied Psychology: Health and Well-Being, 3(1), 1-43. https://doi.org/10.1111/j.1758-0854.2010.01045.x

Diener, Ed, Wirtz, D., Tov, W., Kim-Prieto, C., Choi, D., Oishi, S., \& Biswas-Diener, R. (2010). New Well-being Measures: Short Scales to Assess Flourishing and Positive and Negative Feelings. Social Indicators Research, 97(2), 143-156. https://doi.org/10.1007/s11205-009-9493-y

Ekayani, S., Lathifah, S., Aprillia, V., \& Nashori, F. (2020, Maret 12). Repentance and Subjective Well-being of Muslim College Students who Access Pornography: Selfcontrol as a Moderator. Proceedings of the 1st International Conference on Religion and Mental Health, ICRMH 2019, 18 - 19 September 2019, Jakarta, Indonesia. https://eudl.eu/doi/10.4108/eai.18-9-2019.2293381

Fivush, R., Marin, K., Crawford, M., Reynolds, M., \& Brewin, C. R. (2007). Children's narratives and well-being. Cognition \& Emotion, 21(7), 1414-1434. https://doi.org/10.1080/02699930601109531

Fowler, J. H., \& Christakis, N. A. (2008). Dynamic spread of happiness in a large social network: Longitudinal analysis over 20 years in the Framingham Heart Study. BMJ, 337, a2338. https://doi.org/10.1136/bmj.a2338 
Hasibuan, M. A. I., Anindhita, N., Maulida, N. H., \& Nashori, H. F. (2018). Hubungan antara Amanah dan Dukungan Sosial dengan Kesejahteraan Subjektif Mahasiswa Perantau. Psikohumaniora: Jurnal Penelitian Psikologi, 3(1), 101-116. https://doi.org/10.21580/pjpp.v3i1.2214

Hribernik, J., \& Mussap, A. J. (2010). Research note: Leisure satisfaction and subjective wellbeing. Annals of Leisure Research, 13(4), 701-708. https://doi.org/10.1080/11745398.2010.9686871

Kulczycka, L., Sysa-Jędrzejowska, A., \& Robak, E. (2010). Quality of life and satisfaction with life in SLE patients-The importance of clinical manifestations. Clinical Rheumatology, 29(9), 991-997. https://doi.org/10.1007/s10067-0101509-0

Mahardhika, N. F., \& Halimah, L. (2017). Hubungan Gratitude dan Subjective WellBeing Odapus Wanita Dewasa Awal di Syamsi Dhuha Foundation Bandung. Psympathic: Jurnal Ilmiah Psikologi, 4(1), 91-114. https://doi.org/10.15575/psy.v4i1.1278

Malchiodi, C. A. (2007). Expressive therapies. Guilford Press.

Mcelhone, K., Abbott, J., \& Teh, L.-S. (2006). A review of health related quality of life in systemic lupus erythematosus. Lupus, 15(10), 633-643. https://doi.org/10.1177/0961203306071710

Muzayanah, A. (2016). Konseling kelompok pada penderita lupus. 1-6.

Nazarian, D., \& Smyth, J. (2008). Expressive writing. Dalam Evidence-based adjunctive treatments (hlm. 221-241). Elsevier Academic Press. https://doi.org/10.1016/B978-012088520-6.50012-3

Okun, M. A., Stock, W. A., Haring, M. J., \& Witter, R. A. (1984). Health and Subjective Well-Being: A Meta-Analyis. The International Journal of Aging and Human Development, 19(2), 111-132. https://doi.org/10.2190/QGJN-0N81-5957-HAQD

Pennebaker, J. W., \& Beall, S. K. (1986). Confronting a traumatic event: Toward an understanding of inhibition and disease. Journal of Abnormal Psychology, 95(3), 274-281. https://doi.org/10.1037/0021-843X.95.3.274

Pluth, K. M. (2012). Alexithymia, Emotional Intelligence, and Their Relation to Word Usage in Expressive Writing. Undefined. /paper/Alexithymia\%2C-EmotionalIntelligence\%2C-and-Their-toPluth/687c21100b91c25b224a88ab8e781d757da9c854

Pusdatin. (2017). Pusat Data dan Informasi-Kementerian Kesehatan Republik Indonesia. $\quad$ https://pusdatin.kemkes.go.id/article/view/17072400003/situasipenyakit-lupus-di-indonesia.html

Rahmawati, U. N., Nashori, F., \& Rachmahana, R. S. (2020). Pelatihan Mindfulness Teaching untuk Meningkatkan Kesejahteraan Subjektif Guru Sekolah Inklusi. 
Psympathic: Jurnal Ilmiah Psikologi, 7(1), 49-60. https://doi.org/10.15575/psy.v7i1.8241

Ryan, R. M., \& Deci, E. L. (2001). On Happiness and Human Potentials: A Review of Research on Hedonic and Eudaimonic Well-Being. Annual Review of Psychology, 52(1), 141-166. https://doi.org/10.1146/annurev.psych.52.1.141

Smyth, J. M. (1998). Written emotional expression: Effect sizes, outcome types, and moderating variables. Journal of Consulting and Clinical Psychology, 66(1), 174184. https://doi.org/10.1037/0022-006X.66.1.174

Snyder, C. R., \& Lopez, S. J. (2001). Handbook of Positive Psychology. Oxford University Press.

Soper, B., \& Bergen, C. W. V. (2001). Employment counseling and life stressors: Coping through expressive writing. Journal of Employment Counseling, 38(3), 150-160. https://doi.org/10.1002/j.2161-1920.2001.tb00497.x

Steel, P., Schmidt, J., \& Shultz, J. (2008). Refining the relationship between personality and subjective well-being. Psychological Bulletin, 134(1), 138-161. https://doi.org/10.1037/0033-2909.134.1.138

Toepfer, S., \& Walker, K. (2009). Letters of Gratitude: Improving Well-Being through Expressive Writing. https://doi.org/10.17239/JOWR-2009.01.03.1

Ulfah, K. (2015). Hubungan Self-Compassion dengan Subjective Well-Being pada Mahasiswa Universitas Sumatera Utara. Universitas Sumatera Utara. 